\title{
Oxidant/Antioxidant Status of Erythrocytes from Patients with Chronic Renal Failure: Effects of Hemodialysis
}

\author{
Illker Durak ${ }^{a}$ Mustafa Kavutcu ${ }^{b}$ M.Y. Burak Çimen ${ }^{a}$ Aslıhan Avcı a \\ Serenay Elgün ${ }^{a}$ H. Serdar Öztürk ${ }^{a}$ \\ aBiochemistry Department, Ankara University Medical Faculty, and ' ${ }^{b}$ Gazi University High School of Health, \\ Ankara, Turkey
}

\author{
Key Words \\ Chronic renal failure $\cdot$ Hemodialysis $\cdot$ Oxidant stress
}

\begin{abstract}
Objective: It has been suggested that oxidative processes may be increased in patients with chronic renal failure (CRF), and that this is a possible factor contributing to the development of anemia and atherosclerosis, characteristic complications of CRF. The aim of this study was to investigate erythrocyte oxidant/antioxidant status in patients with CRF and to elucidate possible effects of hemodialysis on erythrocyte antioxidant system. Methods: Fasting blood samples were obtained from 33 patients with CRF and from 12 healthy controls. Of the patients, 17 subjects were under regular hemodialysis. Values of the activities of antioxidant enzymes, namely superoxide dismutase (SOD), glutathione peroxidase (GSH-PX), catalase (CAT) and antioxidant potential, nonenzymatic superoxide radical scavenger activity (NSSA) and levels of thiobarbituric acid reagent substances (TBARS) were measured in the erythrocytes from both patients and controls. Results: Antioxidant potential and NSSA values were found to be significantly decreased, while TBARS levels were increased in the erythrocytes of patients. SOD activity was found to be unchanged, but GSH-Px and CAT activities were significantly lower in the patient group. Moreover, the erythrocyte TBARS level in
\end{abstract}

\section{KARGER}

Fax +41613061234

E-Mail karger@karger.ch

www.karger.com

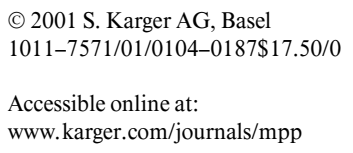

the hemodialysis group was higher than in the controls and nonhemodialysis patients. Conclusion: The results suggest that antioxidant potential is reduced due to impaired antioxidant system in erythrocytes from patients with CRF and that oxidant stress causes significant peroxidation. Hemodialysis is determined to further increase oxidative reactions. These changes seem to contribute to the occurrence of some complications of CRF. Therefore, it has been suggested that antioxidant supplementation may give beneficial results for these patients.

Copyright $\odot 2001$ S. Karger AG, Basel

\section{Introduction}

It has long been known that anemia [1] and cardiovascular diseases [2] are characteristic complications of chronic renal failure (CRF) and there is accumulating evidence indicating that oxidative reactions may play a part in these events $[3,4]$.

Recent data suggest that oxidative processes may be increased in patients with $\mathrm{CRF}$ [3-5]. It has been reported that the enzymatic antioxidant system is impaired in erythrocytes from patients with $\mathrm{CRF}[6,7]$ and that the resulting oxidant load may play a role in the development of some complications of CRF $[8,9]$. It has been reported that oxidative damage due to excessive free radical production is increased in uremic patients, and that this is a
Prof. Dr. İlker Durak

Ankara Üniversitesi Tıp Fakültesi

Biyokimya ABD (Dekanlık Binası)

06100 Sihhiye-Ankara (Turkey)

Tel. +90 312 3092219, Fax +90 312 3106370, E-Mail durak@dialup.ankara.edu.tr 
possible factor contributing to the development of anemia and atherosclerosis [10]. Other studies have revealed increased protein oxidation in the erythrocyte membranes from chronic hemodialysis patients [11].

The study presented here aims to investigate the erythrocyte antioxidant system and the oxidant/antioxidant status of patients with CRF and to elucidate possible molecular mechanisms leading to CRF-related complications, such as anemia and atherosclerosis.

\section{Materials and Methods}

Thirty-three patients with CRF and 12 healthy volunteers participated in the study. Seventeen of the patients were under regular hemodialysis for $1-4$ years (mean \pm SD: $2.6 \pm 1.2$ ). The ages of the patients ranged from 38 to 70 years (mean \pm SD: $51.4 \pm 8.5$ ) and those of the controls from 35 to 56 years (mean \pm SD: $47.8 \pm 5.6$ ). The duration of complaints resulting from renal failure ranged from 1 to 10 years (mean \pm SD: $4.6 \pm 2.7$ ). Diagnosis of CRF was made by clinical, laboratory and radiological examinations.

Fasting blood samples were put in anticoagulated tubes and erythrocytes were prepared as described previously [12]. In the erythrocyte hemolysate, superoxide dismutase (SOD), glutathione peroxidase (GSH-Px) and catalase (CAT) activities were measured [13-15] The SOD activity method is based on the measurement of absorbance increase at $560 \mathrm{~nm}$ due to reduction of nitroblue tetrazolium (NBT) to $\mathrm{NBTH}_{2}$. One unit of SOD activity is defined as the amount of enzyme protein causing a 50\% inhibition in the NBT salt reduction rate. The GSH-Px activity method is based on the measurement of absorbance decrease at $340 \mathrm{~nm}$ due to consumption of NADPH, and that of CAT is based on the measurement of absorbance decrease due to $\mathrm{H}_{2} \mathrm{O}_{2}$ consumption at $240 \mathrm{~nm}$. The GSH-Px and CAT activities were given in international units per milliliter erythrocyte sediment (IU/ml).

The antioxidant potential (AOP) assay was performed using the method of Durak et al. [16] which is mainly based on the determination of thiobarbituric acid reagent substances (TBARS) levels before and after exposure to superoxide radicals produced by the xanthinexanthine oxidase system. In the reaction medium enriched with fish oil, samples (supernatant obtained after centrifugation) were exposed to superoxide radicals $(\mathrm{O} \dot{\overline{2}})$ produced by the xanthine/xanthine oxidase system for $1 \mathrm{~h}$. Fish oil was used because it is a polyunsaturated oil, and polyunsaturated fatty acids are very sensitive to free radical attacks. It is known that if there is an inability of the cell to eliminate free radicals, unsaturated fatty acids will be easily attacked and cause lipid peroxidation followed by an increase in TBRAS levels. By using this reaction system, we think that it is possible to obtain more accurate information concerning the total (enzymatic and nonenzymatic) AOP of the tissue and cells. Therefore, vague TBARS levels of the reaction medium (nmol/g tissue) were measured before (blank) and after (sample) $\mathrm{O} \dot{2}$ radical attack. The difference between both values was inversely proportional to the AOP of the erythrocyte sediment ( $\mathrm{ml}$ erythrocyte sediment $\cdot \mathrm{h} / \mathrm{nmol}$ ).

The nonenzymatic superoxide radical scavenger activity (NSSA) assay was made as described previously [17], and the TBARS assay was carried out using the thiobarbituric acid method [18]. In the NSSA assay, proteins including SOD are first precipitated using tri- chloroacetic acid solution $20 \%(\mathrm{w} / \mathrm{v})$, and then NSSA assay is performed in the upper clear solution without protein as is SOD activity measurement. Using this method, total nonenzymatic (non-SOD) superoxide radical scavenger activity was to be established. One unit of NSSA was defined as the antioxidant activity causing a 50\% inhibition in the NBT salt reduction rate and expressed in the erythrocyte sediment $(\mathrm{U} / \mathrm{ml})$. As to the TBARS analysis, although the TBARS analysis has some disadvantages such as indicating reactions with some peroxidation products other than those of lipids, the intensity of color of the red pigment formed in the TBARS reaction is so great that the method offers great sensitivity in detection and measurement of lipid auto-oxidation. TBARS values were given in nanomoles per milliliter erythrocyte sediment. Blood urea and creatinine levels $(\mathrm{mg} / \mathrm{dl})$ were measured in a routine biochemistry laboratory.

The Student's t test and the Mann-Whitney U test were used for statistical analyses.

\section{Results}

Results are given in table 1. As seen from the table, erythrocyte SOD activity remained unchanged, while GSH-Px and CAT activities were significantly lower in patient groups. Consequently AOP and NSSA values were decreased, but TBARS levels were significantly increased in the patient groups. In the hemodialysis group, the TBARS levels and CAT activities were found to be higher compared with nonhemodialysis patient group. With regard to other parameters, there were no meaningful differences between the patient groups.

\section{Discussion}

The results of the present study demonstrate that the erythrocyte antioxidant system is impaired and antioxidant potential is reduced in the erythrocytes derived from patients with CRF, the results of which are oxidant stress and accelerated peroxidation reactions. As a result, total (reduced AOP), nonenzymatic (reduced NSSA) and enzymatic (decreased enzyme activities) antioxidant systems seem to be impaired in the erythrocytes from patients. In addition, the study shows that hemodialysis induces peroxidation reactions.

It seems that the reduced antioxidant potential due to impaired antioxidant system leads to oxidant stress and peroxidation reactions in the erythrocytes of patients. Impaired antioxidant system may arise from several factors including uremia [10], lowered concentrations of some antioxidant substances like vitamins $\mathrm{E}, \mathrm{C}$ and glutathione etc. [19-21] and inhibition of some free radical enzymes [6, 20, 22-25]. Reduced GSH-Px and CAT activities, on the other hand, may result from reduced 
Table 1. Mean \pm SD values of SOD, GSH-Px, CAT activities, AOP, NSSA and TBARS levels in the erythrocytes from patients and controls

\begin{tabular}{lllllll}
\hline Group & $\begin{array}{l}\text { SOD } \\
\text { U/ml }\end{array}$ & $\begin{array}{l}\text { GSH-Px } \\
\text { IU/ml }\end{array}$ & $\begin{array}{l}\text { CAT } \\
\text { IU/ml }\end{array}$ & $\begin{array}{l}\text { AOP } \\
\mathrm{ml} \cdot \mathrm{h} / \mathrm{nmol}\end{array}$ & $\begin{array}{l}\text { NSSA } \\
\mathrm{U} / \mathrm{ml}\end{array}$ & $\begin{array}{l}\text { TBARS } \\
\mathrm{nmol} / \mathrm{ml}\end{array}$ \\
\hline I (n=12) & $172.2 \pm 13.1$ & $7.18 \pm 0.97$ & $46,055 \pm 6,440$ & $2.71 \pm 0.35$ & $23.9 \pm 4.3$ & $328.9 \pm 30.4$ \\
II (n=16) & $180.0 \pm 23.0$ & $6.65 \pm 0.68$ & $38,987 \pm 5,861$ & $2.39 \pm 0.32$ & $18.8 \pm 4.5$ & $367.9 \pm 29.9$ \\
III (n=17) & $166.3 \pm 24.1$ & $6.17 \pm 0.69$ & $41,449 \pm 5,440$ & $2.36 \pm 0.23$ & $16.9 \pm 3.4$ & $412.8 \pm 22.2$ \\
\hline Mann-Whitney U test & & & & & \\
I-II & NS & $\mathrm{p}<0.05$ & $\mathrm{p}<0.0005$ & $\mathrm{p}<0.01$ & $\mathrm{p}<0.005$ & $\mathrm{p}<0.005$ \\
I-III & $\mathrm{NS}$ & $\mathrm{p}<0.005$ & $\mathrm{p}<0.05$ & $\mathrm{p}<0.005$ & $\mathrm{p}<0.0005$ & $\mathrm{p}<0.0005$ \\
II-III & NS & NS & $\mathrm{p}<0.025$ & $\mathrm{NS}$ & $\mathrm{NS}$ & $\mathrm{p}<0.0005$ \\
\hline
\end{tabular}

$\mathrm{I}=$ Control group; $\mathrm{II}=$ nondialysed $\mathrm{CRF}$ group; $\mathrm{III}=$ dialysed $\mathrm{CRF}$ group; NS = nonsignificant $(\mathrm{p}>0.05)$.

The units are as defined in the 'Materials and Methods' section.

synthesis or inhibition of the enzymes by some inhibitor substances accumulated in the blood of patients with CRF [26]. Deficiency of some trace elements including selenium (Se) might be one of the other factors responsible for the reduced enzyme activities in patients with CRF [22, 26, 27].

Further potential sources of oxidant stress in dialysis patients are, in particular, activation of leukocytes [28] and iron overload [29]. It has been established that hemodialysis itself accelerates lipid peroxidation in blood [30]. It has also been reported that hemodialysis causes a broad pattern of tissue injury in patients on regular hemodialysis [27]. Ross et al. [19] have argued that hemodialysis patients are at increased risk from oxidative stress due to glutathione deficiency in whole blood and erythrocytes. Jackson et al. [9] reported that depletion of some antioxidants leads to accelerated atherogenesis in hemodialysis patients. In general, our results are in accord with these evaluations. Shortened red blood cell survival [31] and changed erythrocyte membrane fluidity [32] may be the results of oxidant stress due to an impaired antioxidant system in the erythrocytes from patients with CRF. These changes may contribute to the occurrence of some complications of CRF like anemia and atherosclerosis etc. [6, 23-25, 32-34].

The findings that when erythrocytes from patients with CRF were given to normal people, the erythrocytes had normal survival times and when erythrocytes from normal people were given to the patients with CRF, they had shortened survival times $[35,36]$ suggest that primary factors responsible for the shortened erythrocyte survival were present in the circulation. Inhibitor substances accumulating in uremia [31], increased serum neuraminidase activity [37], changed erythrocyte membrane fluidity
[38], impaired Na-K pump system in the erythrocytes [39] and increased purine/pyrimidine content in uremic hemolysates [40] have all been suggested to contribute to the hemolysis in patients with CRF. In addition to reduced antioxidant potential, artifacts occurring during dialysis, several uremic metabolites [31], oxidative stress due to hexose monophosphate shunt inhibition $[23,24]$ and reduced ATP/ADP ratio due to oxidative metabolism [40] may all contribute to the increased toxic-free radical production in the erythrocytes. Similarly, the metabolites of some drugs and urea [31, 41], exposure to some toxic trace elements like aluminium, silicon etc. during dialysis [34] may also be additional factors leading to oxidant stress and peroxidation reactions in the hemodialysis patients.

Apart from the observation that enzymatic (decreased enzyme activities) antioxidant systems are impaired in the erythrocytes of patients, this study also shows that nonenzymatic (reduced NSSA) antioxidant defense and AOP of the erythrocytes are reduced, which is a new finding in patients with CRF.

\section{Conclusion}

Our results demonstrate that oxidant/antioxidant equilibrium is changed in the erythrocytes in patients with CRF, and that erythrocytes and possibly some other tissue cells are exposed to great oxidant stress, the results of which are accelerated peroxidation reactions and cellular aberrations. It is therefore suggested that antioxidant supplementation may help CRF patients to cope with oxidant stress and prevent peroxidation reactions leading to cellular dysfunction. 


\section{References}

1 Eschbach JW, Adamson JW: Anemia of endstage renal disease (ESRD). Kidney Int 1985 ; 28:1-5.

2 Degoulet P, Legrain M, Reach I, Aime F, Devries $\mathrm{C}$, Rojas $\mathrm{P}$, Jacobs C: Mortality risk factors in patients treated by chronic hemodialysis. Nephron 1982;31:103-110.

3 Marshall P, Warso MA, Lands WE: Selective microdetermination of lipid hydroperoxidase. Anal Biochem 1985;145:192-199.

4 Santos MT, Valles J, Aznar J, Vilches J: Determination of plasma malondialdehyde-like material and its clinical application in stroke patients. J Clin Pathol 1980;33:973-976.

5 Berger HM, Lindeman JH, van Zoeren-Grobben D, Houdkamp E, Schrijver J, Kanhai HH: Iron overload, free radical damage, and rhesus haemolytic disease. Lancet 1990;335:933-936.

6 Durak I, Akyol Ö, Başeşme E, Canbolat O, Kavutcu M: Reduced erythrocyte defense mechanisms against free radical toxicity in patients with chronic renal failure. Nephron 1994;66:76-80

7 Ong-awyooth L, Ong-ajyooth S, Tiensong K, Nilwarangkur S: Reduced free radical scavengers and chronic renal failure. J Med Assoc Thai 1997;80:101-108.

8 Loughrey CM, Young IS, Lightbody JH, McMaster D, McNamee PT, Trimble ER: Oxidative stress in haemodialysis. QJM 1994;87: 679-683.

9 Jackson P, Loughrey CM, Lightbody JH, McNamee PT, Young IS: Effect of hemodialysis on total antioxidant capacity and serum antioxidants in patients with chronic renal failure. Clin Chem 1995;41:1135-1138.

10 McGrath LT, Douglas AF, McClean E, Brown JH, Doherty CC, Johnston GD, Archbold GP Oxidative stress and erythrocyte membrane fluidity in patients undergoing regular dialysis. Clin Chim Acta 1995;235:179-188.

11 Haklar G, Yeğenağa I, Yalçin AS: Evaluation of oxidant stress in chronic hemodialysis patients: Use of different parameters. Clin Chim Acta 1995;234:109-114.

12 Beutler E: Glucose 6-phosphate dehydrogenase; in Beutler E (ed): Red Cell Metabolism: A Manual Biochemical Procedure. New York, Grune \& Stratton, 1975, pp 66-69.

13 Durak I, Canbolat O, Kavutcu M, Öztürk HS Yurtarslani Z: Activities of total, cytoplasmic and mitochondrial superoxide dismutase enzymes in sera and pleural fluids from patients with lung cancer. J Clin Lab Anal 1996;10:1720.

14 Paglia DE, Valentine WN: Studies on the quantitative and qualitative characerization of erythrocyte glutathione peroxidase. J Lab Clin Med 1967;70:158-169.

15 Aebi H: Catalase; in Bergmeyer HU (ed) Methods of Enzymatic Analysis. New York, Academic Press, 1974, pp 673-677.
16 Durak İ, Karabacak Hİ, Büyukkoçak S, Cimen MY, Kaçmaz M, Ömeroğlu E, Öztürk HS: Impaired antioxidant defense system in the kidney tissues from rabbits treated with cyclosporine: Protective effects of vitamins E and C. Nephron 1998;78:207-211.

17 Durak İ, Canbolat O, Kaçmaz M, Özgen G, Öztürk HS: Antioxidant interferences in superoxide dismutase activity methods using superoxide radical as substrate. Clin Chem Lab Med 1998;36:407-408.

18 Van Ye TM, Roza AM, Pieper GM, Henderson $\mathrm{J}$ Jr, Johnson CP, Adams MB: Inhibition of intestinal lipid peroxidation does not minimize morphological damage. J Surg Res 1993;55: 553-558.

19 Ross EA, Koo LC, Moberly JB: Low whole blood and erythrocyte levels of glutathione in hemodialysis and peritoneal dialysis patient. Am J Kidney Dis 1997;30:489-494.

20 Vanella A, Geremia E, Pinturo R, Tiriolo P, Liuzzo G, Tiriolo Custorella A, Condorelli G, Giglio A: Superoxide dismutase activity and reduced glutathione content in erythrocytes or uremic patients on chronic dialysis. Acta Haematol 1983;70:312-315.

21 Asayama K, Uchida N, Nakane T, Hayashibe H, Dobashi K, Amemiya S, Kato K, Nakazawa $\mathrm{S}$ : Antioxidants in the serum of children with insulin-dependent diabetes mellitus. Free Radic Biol Med 1993;15:597-602.

22 Chen CK, Laiw JM, Juang JG, Lin TH: Antioxidant enzymes and trace elements in hemodialyzed patients. Biol Trace Elem Res 1997;58: 149-157.

23 El-Rashidy FH, Al-Turk WA, Stohs SJ: Glutathione, glutathione reductase and glutathione S-transferase activities in erythrocytes and lymphocytes in chronic renal disease. Res Commun Chem Pathol Pharmacol 1984;44: 423-430.

24 Seth RK, Saini AS, Aggarwal SK: Glutathione peroxidase activity and reduced glutathione content in erythrocytes in patients with chronic renal failure. Scand J Haematol 1985;35:201204.

25 Shainkin-Kestenbaum R, Caruso C, Berlyne GM: Reduced superoxide dismutase activity in erythrocytes of dialysis patients. A possible factor in the etiology of uremic anemia. Nephron 1990;55:251-253.

26 Ceballos-Picot I, Witko-Sarsat V, Merad-Boudia M, Nguyen AT, Thevenin M, Jaudon MC, Zingraff J, Verger C, Jungers P, Descamps-Latscha B: Glutathione antioxidant system as a marker of oxidative stress in chronic renal failure. Free Radic Biol Med 1996;21:845-853.

27 Koenig JS, Fischer M, Bulant E, Tiran B, Elmadfa I, Druml W: Antioxidant status in patients on chronic hemodialysis therapy: Impact of parenteral selenium supplementation. Wien Klin Wochenschr 1997;109:13-19.
28 Nguyen AT, Lethias C, Zingraff J, Herbelin A Naret C, Descamps-Latscha B: Hemodialysis membrane-induced activation of phagocyte oxidative metabolism detected in vivo and in vitro within microamounts of whole blood. Kidney Int 1985;28:158-167.

29 Peuchant E, Carbonneau M-A, Dubourg L, Thomas MJ, Perromat A, Vallot C, Clerc M: Lipoperoxidation in plasma and red blood cells of patients undergoing hemodialysis: Vitamins A, E and iron status. Free Radic Biol Med 1994;16:339-346.

30 Mohora M, Mircescu G, Cirjan C, Mihailescu I, Girneata L, Ursea N, Dinu V: Effect of hemodialysis on lipid peroxidation and antioxidant system in patients with chronic renal failure. Rom J Intern Med 1995;33:237-242.

31 Jacob HS, Eaton JW, Yawata Y: Shortened blood cell survival in uremic patients: Beneficial and deleterious effects of dialysis. Kidney Int 1975; 7(suppl 2):139-143.

32 Hasselwander O, Young IS: Oxidative stress in chronic renal failure. Free Radic Res 1998;29: $1-11$.

33 Paul JL, Man NK, Moatti N, Raichvarg D: Membrane phospholipid peroxidation in renal insufficiency and chronic hemodialysis. Nephrologie 1991;12:4-7.

34 Turi S, Nemeth I, Vargha I, Matkovics B, Dobos E: Erythrocyte defense mechanisms against free oxygen radicals in haemodialysed uremic children. Pediatr Nephrol 1991:5:179_ 183

35 Moriyama Y, Rege A, Fisher JW: Studies of an inhibitor of erythropoiesis. II. Inhibitory effects of serum from uremic rabbits on heme synthesis in rabbit bone marrow cultures. Proc Soc Exp Biol Med 1975;148:94-97.

36 Bogin E, Massry SG, Levi J, Djaldeti M, Bristol $\mathrm{G}$, Smith J: Effect of parathyroid hormone on osmotic fragility of human erythrocytes. J Clin Invest 1982;69:1017-1025.

37 Levinsky H, Gafter U, Levi J, Allalouf D Neuraminidase like activity in sera of uremic anemic patients. Nephron 1984;37:35-38.

38 Komidori K, Kamada T, Yamashita T, Harada R, Otsuji Y, Hashimoto S, Chuman Y, Otsuji $\mathrm{S}$ : Erythrocyte membrane fluidity decreased in uremic hemodialysed patients. Nephron 1985 ; 40:185-188.

39 Izumo H, Izumo S, DeLuise M, Flier JS: Erythrocyte Na-K pump in uremia: Acute correction of a transport defect by hemodialysis. J Clin Invest 1984;74:581-588.

40 Angle CR, Swanson MS, Stohs SJ, Markin RS Abnormal erythrocyte pyrimidine nucleotides in uremic subjects. Nephron 1985;39:169_ 174.

41 Giovannetti S, Cioni L, Balestri PL, Baiginini $\mathrm{M}$ : Evidence that guanidines and some related compounds cause hemolysis in chronic uremia. Clin Sci 1968;34:141-148 